\title{
CHEMICAL CHARACTERIZATION OF BARK COMPOUNDS FROM CAATINGA SPECIES
}

\author{
Thiago Cardoso Silva ${ }^{1^{*}}$, Rafael Leite Braz ${ }^{2}$, Emmanoella Costa Guaraná Araujo ${ }^{3}$, Gisely Alves da Silva ${ }^{4}$, Maria \\ de Los Angeles Perez Fernandez Palha ${ }^{5}$
}

\begin{abstract}
${ }^{1 *}$ Universidade Federal do Paraná, Pós-Graduação em Engenharia Florestal, Curitiba, Paraná, Brasil - thiagocardoso.pe@ gmail.com ${ }^{2}$ Universidade Federal Rural de Pernambuco, Departamento de Ciência Florestal, Recife, Pernambuco, Brasil - rlbraz.ufrpe@ gmail.com

${ }_{3}^{3}$ Universidade Federal do Paraná, Pós-Graduação em Engenharia Florestal, Curitiba, Paraná, Brasil - manuguarana@gmail.com ${ }^{4}$ Universidade Federal de Pernambuco, Pós-Graduação em Engenharia Química, Recife, Pernambuco, Brasil - giselly_asilva@hotmail.com ${ }_{5}^{5}$ Universidade Federal de Pernambuco, Departamento de Engenharia Química, Recife, Pernambuco, Brasil - angelesufpe@yahoo.com.br
\end{abstract}

Received for publication: 22/05/2020 - Accepted for publication: 08/01/2021

\begin{abstract}
Resumo
Caracterização química dos compostos da casca de espécies da Caatinga. O estudo teve como objetivo caracterizar quimicamente os extratos de casca de espécies arbóreas: Anacardium occidentale L., Ziziphus joazeiro Mart. e Mimosa caesalpiniaefolia Benth.; utilizando como solventes a água, álcool e hexano. As cascas foram coletadas nos galhos das três espécies. Este material foi pré-seco e moído. A determinação do teor de extrativos, quantificando extrativos totais nas amostras, utilizando o método Sohxlet, e a determinação do teor de extrativos solúvel em água, álcool etílico e hexano. Em relação à sua composição química, os extratos foram analisados por meio da análise por Espectroscopia no Infravermelho Próximo (NIR). O conteúdo extrativo nas três espécies se comportou de maneira semelhante, sendo o hexano o solvente que extraiu mais compostos e juazeiro a espécie que apresentou o maior teor total de extrativos. Com a caracterização química dos extratos, foi possível identificar a presença de grupos funcionais característicos de carboidratos e proteínas nos extratos aquosos; a presença de grupos hidroxilos característicos, por exemplo em álcoois, aldeídos, cetonas e éteres, nos extratos etanólicos; e a presença de ácidos graxos e compostos aromáticos (óleos essenciais) em extratos hexanólicos. Os óleos essenciais foram os compostos que apresentaram maiores quantidades, podendo ser explorados pela indústria farmacêutica.

Palavras-chave: composição química; produtos florestais não madeireiros; Espectroscopia no Infravermelho Próximo (NIR); compostos solúveis; produtos naturais
\end{abstract}

\section{Abstract}

This study aimed to chemically characterize the bark extracts from three tree species: Anacardium occidentale L., Ziziphus joazeiro Mart. and Mimosa caesalpiniaefolia Benth., in addition to obtaining the soluble extract content in water, alcohol and hexane from the bark of these species. The bark was collected from branches of the three species and subsequently pre-dried and milled. The extract content was then determined using the Sohxlet method aiming to quantify the total extractives in the samples, and determine the extract content soluble in water, ethyl alcohol and hexane. The extracts were further analyzed by Near Infrared Spectroscopy (NIRS) analysis to determine their chemical composition. The extract contents in the three species behaved in a similar way, with hexane being the solvent which extracted more compounds and juazeiro the species that displayed the highest total extract content. With the chemical characterization of the extracts, it was possible to identify the presence of functional groups characteristic of carbohydrates and proteins in the aqueous extracts; the presence of characteristic hydroxyl group, for example in alcohols, aldehydes, ketones and ethers in the ethanolic extracts; and the presence of fatty acids and aromatic compounds (essential oils) in hexanolic extracts. The essential oils were the compounds which presented larger quantities, and can be exploited by the pharmacochemical industry.

Keywords: chemical composition; non-timber forest products; Near Infrared Spectroscopy (NIRS); soluble compounds; natural products

\section{INTRODUCTION}

The use of natural products from forests in Brazilian semi-arid regions began with the country's colonization process, leading to increasing pressure on the continuous exploitation of wood resources for construction, firewood and handicrafts, as well as extraction of fruit, seeds, bark and many other products along with the use of these resources as fodder. Thus, two issues are fundamental when it comes to raising awareness towards the sustainable use and conservation of forest resources in the Caatinga biome (GARIGLIO et al., 2010): (a) the importance of maintaining the regional economy, which is often sustained by the exploitation of these resources for their own use, such as fodder for livestock and for income generation; and (b) standardizing management of these resources, aiming to guarantee balanced production in the future.

Therefore, sustainable exploitation of forest resources is essential, especially when handling parts of the tree which recompose more easily such as leaves, fruits, seeds and branches. Thus, several species in the Caatinga 
stand out with these characteristics for the potential industrial use of their wood and non-timber products, such as the use of angico bark (Anadenanthera colubrina var. cebil), which is species used in traditional tanneries for tanning skins from the Brazilian semi-arid region (LIMA et al., 2014), as well as the cashew (Anacardium occidentale L.), juazeiro (Ziziphus joazeiro Mart.) and sabiá (Mimosa caesalpiniaefolia Benth.) trees. Lins et al. (2019) recommend evaluating the species of this phytogeographic domain, aiming at exploiting the chemical compounds present in the bark and branches of these trees according to the proper manegement of their products.

Since wood has different uses, it is fundamental to know the chemical characteristics it has, as these properties in terms of compound quantity and quality are essential to determine the best use of each tree species. Therefore, in addition to taking advantage of the wood with its natural characteristics, it is important to adapt it to the most diverse uses in order to add value to the species. The variations which occur in the chemical properties of the wood are related to the species characteristics, origin and development capacity under any conditions the place may be. Accordingly, the aim is to produce raw materials in a greater quantity and quality which are suitable for manufacturing different wood-based products (GUIMARÃES JR et al., 2011; GUIMARÃES et al., 2013).

Wood has a chemical composition that is different from the other structures of vegetal tissues, with these compounds having several anatomical, morphological and physiological functions. the wood is chemically divided into two major groups of components: structural ones (cellulose, hemicellulose and lignin), which are part of the cell wall; and the accidentals, secondary compounds or non-structurals (mineral and extractive), which do not structurally constitute the cell wall.

Extractive contents are quite expressive among the components considered as secondary in terms of wood content, and generally make up between 3 and $10 \%$ of the mass from the dry woody material, with some tropical species being able to have values higher than $10 \%$; moreover, they are responsible for giving several characteristics to the wood such as color, smell, taste, natural resistance to rotting and abrasive properties (SJÖSTRÖM, 1993; KLOCK; ANDRADE, 2013). Extracts are present in several parts of the plants, mainly participating in the chemical constitution of the wood in general, as in the cases of the trunk, branches, bark and roots, differing in their extractive content and chemical composition in each organ. Bark has a higher extractive content than wood because of its protective function. Therefore, bark management is necessary to exploit these resources without cutting the trees.

Near Infrared Spectrometry (NIRS) stands out among chemical characterization analysis methods due to the fact that it is a method in which there is no residue production and it does not require destroying the samples. Futhermore, it has the advantage of acquiring faster results and smaller needs for labor, and consequently lower cost when compared to physico-chemical analysis methods (SANTOS et al., 2012).

The technique consists in exposing the sample to the spectrum in the infrared region, generally with the wavelength ranging from 750 to $2500 \mathrm{~nm}$, obtaining correlations between these wavelengths and the actions of reflectance, absorbance and transmittance of the response to exposure (JONES et al., 2020). The graphs are then constructed according to the obtained values, and these are correlated with tabulated values which correspond to the identified variables in each spectrum. Thus, the chemical composition of the samples can be evaluated.

In view of the above, this study aimed to chemically characterize the bark extracts from three tree species: Anacardium occidentale L., Ziziphus joazeiro Mart., and Mimosa caesalpiniaefolia Benth., in addition to obtaining the soluble extract content in water, alcohol and hexane from the bark of these species.

\section{MATERIAL AND METHODS}

\section{Collection and preparation of samples for extraction}

The materials used in this study were the species Anacardium occidentale L., Ziziphus joazeiro Mart. and Mimosa caesalpiniaefolia Benth., due to being featured in the Caatinga phytogeographic domain in Brazil, in addition to the extract potential present in their wood reported in the literature. Young branches (to facilitate bark separation) with an average diameter of $5 \mathrm{~cm}$ were selected and collected from at least three adult individuals of each species, producing a composite sample. The collections were carried out in January.

A pre-dried in open air sample was initially prepared with the bark of each species. After being separated from trunks, the three different barks were reduced to small fragments ( 5 to $10 \mathrm{~mm}$ ) and taken to the drying oven at $55 \pm 5^{\circ} \mathrm{C}$ in order to dehydrate for $48-72$ hours or until reaching a constant weight. After this time, the samples were milled in a Willey knife mill with a $2 \mathrm{~mm}$ particle selection, and stored and preserved in a sealed container.

\section{Chemical analysis and analysis of the results}

The total extract contents in the prepared bark samples were quantified according to the ABCP M3/69 standard method (ABTCP, 1974), and the soluble extract content in water, ethyl alcohol (PA) and hexane (PA) were determined by the Sohxlet method. Five replicates were performed per treatment, and statistical analysis was performed using analysis of variance (ANOVA). The means of total extracts and among species and the solvents 
were compared using the Tukey's test at $95 \%$ probability using the Assistat program (7.7 beta), by factorial analysis (factor 1: species; factor 2: solvent), in an entirely randomized design.

The extracts were also analyzed by near-infrared spectroscopy using a "PerkinElmer FrontierTM FT-NIR spectrometer" to determine their chemical composition, and the results were treated by the "Spectrum quant" software program in order to determine the main functional groups presents in each extract.

The extracts were prepared from the Soxhlet system extraction using distilled water, ethyl alcohol (pro analyse) and hexane (pro analyse) as solvents in order to obtain extracts with different chemical characteristics for each species. Thus, $200 \mathrm{~g}$ of pre-dried bark were used for one liter of solvent, with this being the concentration of the extracts. Next, three graphs were constructed for each type of extract as a function of transmittance $(\%)$ and absorption region $\left(\mathrm{cm}^{-1}\right)$, which were interleaved to produce a final graph that best represented the functional groups present. These graphs were then compared with those regarding the used pure solvents, so that the results only showed the characteristics present in the extracts. The peaks which correspond to the functional groups present in each extract were evaluated according to the standardized data and tabulated (RIBEIRO; SOUZA, 2007; PERIOTTO, 2012).

Finally, a Principal Component Analysis (PCA) was performed to observe the interaction between the species and the compounds present in the bark. This analysis was performed in the R software.

\section{RESULTS}

\section{Extractive contents in the barks}

Among the three evaluated species, the $Z$. joazeiro displayed the highest total extractive content in its bark $(8.05 \%)$ when compared to A. occidentale $(7.12 \%)$ and the M. caesalpiniaefolia (7.20\%). For all species, hexane was the solvent which most extracted compounds, differing from the amount extracted using water and ethyl alcohol (Table 1).

Table 1. Mean mass/mass contents $(\%-\mathrm{m} / \mathrm{m})$ ratio in bulk extracts from Anacardium occidentale L., Ziziphus joazeiro Mart. and Mimosa caesalpiniaefolia Benth. tree bark soluble in water, ethyl alcohol and hexane.

Tabela 1. Teores médios da relação massa/massa $(\%-\mathrm{m} / \mathrm{m})$ de extrativos na casca das espécies Anacardium occidentale L., Ziziphus joazeiro Mart. e Mimosa caesalpiniaefolia Benth. solúveis em água, álcool estílico e hexano.

\begin{tabular}{cccc}
\hline \multirow{2}{*}{ SOLVENT } & \multicolumn{3}{c}{ EXTRACTIVE CONTENTS $(\%-\mathrm{m} / \mathrm{m})$} \\
\cline { 2 - 4 } & A. occidentale & Z. joazeiro & M. caesalpiniaefolia \\
\hline Water & $1.87 \mathrm{bAB}$ & $2.00 \mathrm{bA}$ & $1.61 \mathrm{cB}$ \\
Ethyl alcohol & $2.10 \mathrm{bB}$ & $2.23 \mathrm{bB}$ & $2.54 \mathrm{bA}$ \\
Hexane & $3.15 \mathrm{aB}$ & $3.82 \mathrm{aA}$ & $3.05 \mathrm{aB}$ \\
\hline TOTAL EXTRACTIVES & $7.12 \mathrm{~B}$ & $8.05 \mathrm{~A}$ & $7.20 \mathrm{~B}$ \\
\hline
\end{tabular}

Means followed by the same letter do not differ statistically from each other by the Tukey test at the 95\% probability level. The lowercase letters represent a comparison of the solvents for each species (column) and the uppercase letters represent the comparison of the different species for each solvent (lines).

\section{Characterization of the compounds present in the barks}

The chemical characterization of the extracts was carried out based on the presence of organic functional groups extracted by the solvents. After obtaining the graphs from the NIRS readings and treating them using the Spectrum quant software program, we observed the formation of peaks (absorption bands) generated by the relation between transmittance $(\%)$ and absorption region $\left(\mathrm{cm}^{-1}\right)$. The absorption bands in the near-infrared spectrum for organic compounds vary between 600 and $3600 \mathrm{~cm}^{-1}$ regions, and the functional groups from the compounds present in the extracts can be characterized according to tabulated values (PERIOTO, 2012).

According to the PCA (Figure 1), the first principal component displayed a value below 50\%, and explained $43.04 \%$ of the total variation. Furthermore, the eigenvectors representing the species are negatively high for this component. When evaluating the second principal component, which presented $34.44 \%$ from the total variation, the best responses were obtained by the cashew tree species, with highly negative eigenvectors for this component. 


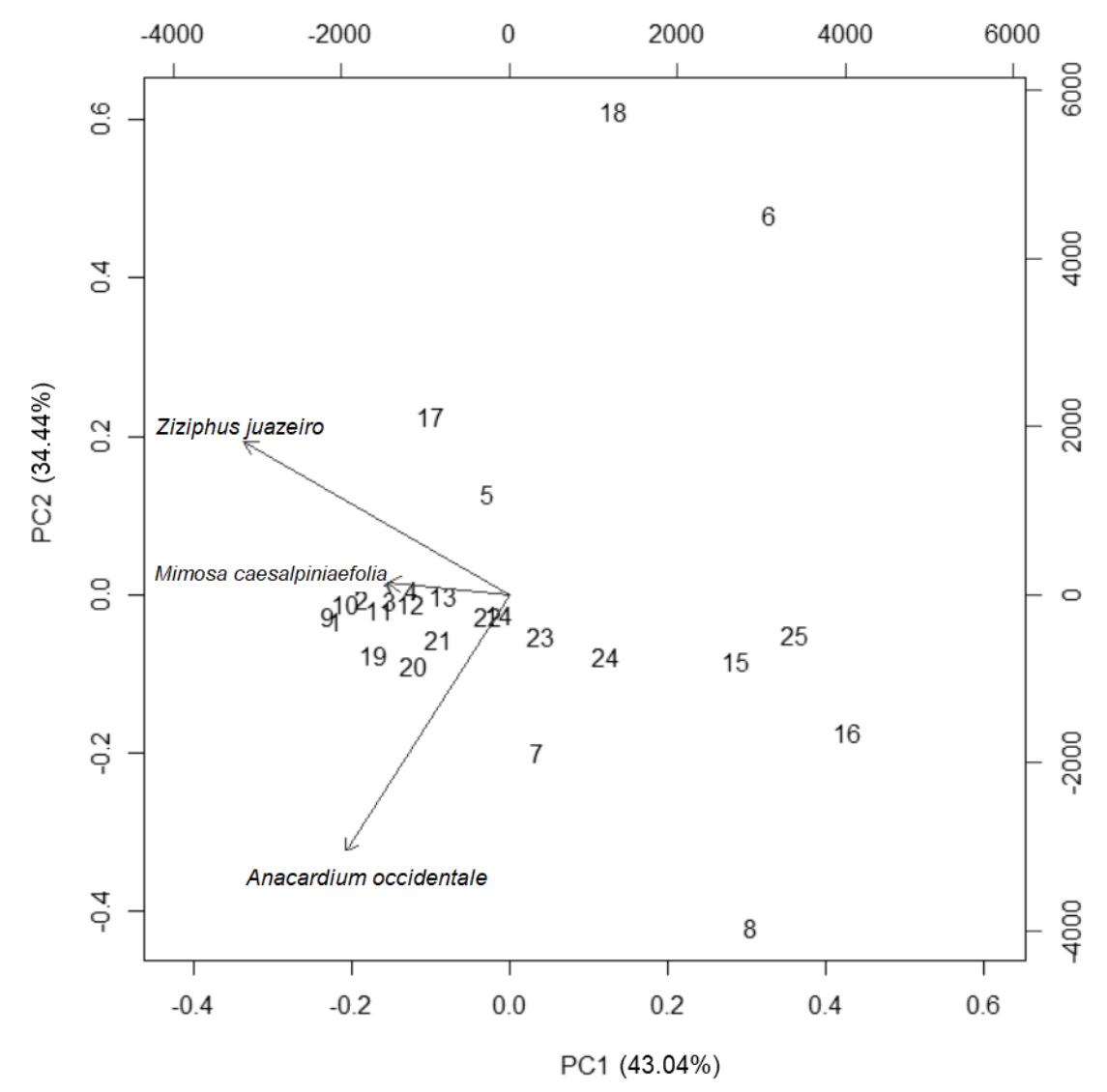

Figure 1. Principal Component Analysis (PCA) of extracts from Anacardium occidentale L., Ziziphus joazeiro Mart. and Mimosa caesalpiniaefolia Benth. bark as a function of the different compounds obtained using water, ethyl alcohol and hexane as solvents.

Figura 1. Análise de Componentes Principais (ACP) dos extrativos das cascas das espécies cajueiro Anacardium occidentale L., Ziziphus joazeiro Mart. e Mimosa caesalpiniaefolia Benth., em função dos diferentes compostos obtidos utilizando água, álcool etílico e hexano como solventes.

\section{DISCUSSION}

\section{Extractive contents in the three barks}

Regarding extractive contents in A. occidentale, most publications report that the species has high levels in the bark of above $10 \%$, and is indicated for the pharmaceutical industry depending on the method used for extraction (VILAR et al., 2016). Therefore, it is observed that the extraction method applied in this study presented greater efficiency in extracting organic compounds, since the Soxhlet method was used in a way that the solvent circulates through the sample several times by means of reflux.

The Z. joazeiro species presented the highest total extractive content, and the literature points to the bark of the trunk being highly used for medicinal purposes, as it contains low levels of toxic tannins and have saponins and triterpene steroids in its composition (MELO et al., 2012). Therefore, there is high potential to exploit the chemical compounds present in this species for various products, encouraging correct management of this bark.

When carrying out the physico-chemical characterization of M. caesalpiniaefolia wood, other authors found a total extractive percentage of $9.0 \%$ using cyclohexane as a solvent, which has the capacity to extract almost all groups of organic compounds (GONÇALVES et al., 2010). There is a high percentage of tannins among these compounds, which may serve as another alternative for using this species in the chemical industry.

The total extractive contents in the barks of the three species were lower than wood from other Caatinga species, such as Anadenanthera colubrina (Vell.) Brenan, var. cebil (Gris.) Alts., Tabebuia aurea (Mart.) Bureau., and Amburana cearenses (Allem.) A.C.Sm., which presented heartwood levels corresponding to 9.86\%, 14.74\% and $13.59 \%$, respectively (PAES et al., 2013). It is also observed that M. caesalpiniaefolia wood presents approximately $20 \%$ more organic compounds when compared to the result of $7.2 \%$ from extractives in the bark. 
This variation may be characteristic of the species, since the chemical composition varies between plant organs (SJÖSTRÖM, 1993; KLOCK; ANDRADE, 2013).

\section{Characterization of the compounds present in the three barks}

The aim when using the near infrared spectrometry (NIRS) evaluation was to obtain results faster and standardized with the literature. The NIRS method has the advantages of being a non-destructive method in some types of analyzes, there is no generation of residues and it is quick to obtain results when compared with other chemical methods (VAZ JÚNIOR, 2015). The cashew tree, juazeiro and sabiá extracts showed different characteristics according to the solvents used for extraction.

First, similar trasmittance peaks were observed in the characterization of the aqueous extracts from the three species, evidencing the presence of $\mathrm{OH}$ functional groups (associated) with formation of polymeric bonds (peak $3504.04 \mathrm{~cm}^{-1}$ ) and $\mathrm{NH}$ groups derived from amines or amides (peak $3128.0 \mathrm{~cm}^{-1}$ ). These two functional groups are characteristic in carbohydrate and protein structures, and both are compounds extracted with water (SJÖSTRÖM, 1993; KLOCK; ANDRADE, 2013). The presence of amides in the barks is related to the antimicrobial protection, since the presence of bioactive secondary metabolites, as in the case of some amide compounds, have potential to be used as an antibiotic when isolated (CUNICO et al., 2004). The aqueous juazeiro extract still presented characteristics from the $\mathrm{C} \equiv \mathrm{C}$ group, possibly due to the presence of asymmetric acetylenic hydrocarbons (peak $2201.5 \mathrm{~cm}^{-1}$ ), discharacterizing the presence of single chain alkynes, since they are insoluble in water (CARNEIRO 2010), and observing a possible relationship of this group with nitriles.

The presence of O-H groups was also verified for the ethanolic extracts, but probably due to the presence of compounds with chemical affinities such as alcohol, ketones, ethers, esters and other organic structures (peaks 3190.0, 3189.7 and $3186.8 \mathrm{~cm}^{-1}$ ). It was possible to observe that other $\mathrm{OH}$ structures were also identified at these same peaks forming chelates, and may have occurred as a mechanism to expel excess free heavy metals which are present in tissues, contributing to form rich peptides in a thiol group, such as phytochelatins and metallothioneins, and for the chelation of these metals by organic acids and amino acids (CLEMENS, 2001; PONGRAC et al., 2009). These chelate-forming compounds have high nutritional values and can serve as supplementation for metals such as zinc, copper and calcium, in addition to the use of the latter in intracellular homeostasis treatments (WANG et al., 2012; PAVAN et al., 2016). The juazeiro extracts also displayed peaks with characteristics from the $\mathrm{C} \equiv \mathrm{C}$ functional groups, possibly of asymmetric hydrocarbons (peak $2248.5 \mathrm{~cm}^{-1}$ ).

It was possible to observe the presence of associated O-H groups in the hexanolic extracts (peak 3342.6 $\mathrm{cm}^{-1}$ ). In addition, the presence of C-H groups from aliphatic and aromatic alkenes were verified (peaks 3107.4, $3069.1,3066.2,3063.2$ and $2969.1 \mathrm{~cm}^{-1}$ ), with the latter forming the essential oil chains which have proven antibiotic actions by the literature, showing potential control of phytopathogens due to the direct fungitoxic action that these compounds have, inhibiting the micelial growth and germination of fungal spores (ROZWALKA et al., 2008).

\section{CONCLUSIONS}

- The extractive contents in the tree species (Anacardium occidentale L., Ziziphus joazeiro Mart. and Mimosa caesalpiniaefolia Benth.) behaved in a similar way, with hexane being the solvent which extracted more compounds and the $Z$. joazeiro being the species which displayed the highest total extractive content;

- From the chemical characterization of the extracts, it was possible to identify the presence of functional groups characteristic of carbohydrates and proteins in the aqueous extracts; the presence of characteristic hydroxyl groups, for example in alcohols, aldehydes, ketones and ethers in the ethanolic extracts; and the presence of fatty acids and aromatic compounds (essential oils) in hexanolic extracts;

- The three species still present chelate groups from pigment and other structures that have metallic ions in their bark composition.

\section{ACKNOWLEDGMENTS}

This study was financed in part by the Coordenação de Aperfeiçoamento de Pessoal de Nível Superior Brasil (CAPES) - Finance Code 001.

\section{REFERENCES}

ASSOCIAÇÃO BRASILEIRA TÉCNICA DE CELULOSE E PAPEL. Normas técnicas ABCP - Norma M3/69. São Paulo: ABTCP 1974.

CARNEIRO, M. S. S. Introdução à química orgânica. Módulo Q7. Rio de Janeiro: Educa, 2010, 53 p. 
CLEMENS, S. Molecular mechanisms of plant metal homeostasis and tolerance. Planta, [n.1.], v. 212, n. 4, p. 475-486, 2001.

CUNICO, M. M.; CARVAlhO, J. L. S.; SILVA, V. C.; MONTRUCCHIO, D. P.; KERBER, V. A.; GRIGOLETTÍ JÚNIOR, A.; AUER, C. C.; MIGUEL, M. D.; MIGUEL, O. C. 2004. Avaliação antifúngica de extratos obtidos de Ottonia martiana Miq. (Piperaceae) sobre três fitopatógenos. Arquivos do Instituto Biológico, São Paulo, v. 71 (supl.), 2004.

GARIGLIO, M. A.; SAMPAIO, E. V. S. B.; CESTARO, L. A.; KAGEYAMA, P. Y. Uso sustentável e conservação dos recursos florestais da caatinga. Brasília: SFB, 2010, 368p.

GONÇALVES, C. A.; LELIS, R. C. C.; ABREU, H. S. Caracterização físico-química da madeira de sabiá (Mimosa caesalpiniaefolia Benth.). Caatinga, Mossoró, v. 23, n. 1, p. 54-62, 2010.

GUIMARÃES, I. L.; GUIMARÃES JR, J. B.; LISBOA, F. J. N.; ANDRADE, C. R.; SIQUEIRA, H. F. Caracterização química e física da madeira de procedências de Eucalyptus. Enciclopédia Biosfera, Jandaia, v. 9, n. 17, p. 636-645, 2013.

GUIMARÃES JR, J. B.; MENDES, L. M.; MENDES, R. F.; MORI F. A. Painéis de madeira aglomerada de resíduos da laminação de diferentes procedências de Eucalyptus grandis, Eucalyptus saligna e Eucalyptus cloeziana. Cerne, Lavras-MG, v. 17, n. 4, p. 443-452, 2011.

JONES, J.; EYLES, A.; CLAYE, C.; RODEMANN, T.; DAMBERGS, B.; CLOSE, D. Prediction of starch reserves in intact and ground grapevine cane wood tissues using near-infrared reflectance spectroscopy. Journal of the Science of Food and Agriculture, London, v. 100, p. 2418-2424, 2020.

KLOCK, U.; ANDRADE, A. S. Química da madeira. 4 ed. Curitiba: UFPR, 2013, 87p.

LIMA, C. R.; PAES, J. B.; LIMA, V. L. A.; DELGADO, M. F. F.; LIMA, R. A. Potencialidade dos extratos tânicos de três espécies florestais no curtimento de peles caprinas. Revista Brasileira de Engenharia Agrícola e Ambiental, Campina Grande, v. 18, n. 11, p. 1192-1197, 2014.

LINS, T. R. S.; BRAZ, R. L.; SILVA, T. C.; ARAUJO, E. C. G.; MEDEIROS, J. X.; REIS, C. A. Tannin content of the bark and branch of Caatinga species. Journal of Experimental Agriculture International, [n.1.], v. 31, n. 1 , p. 1-8, 2019.

MELO, M. S. F.; ROCHA, C. Q.; SANTOS, M. H.; CHAVASCO, J. M.; CHAVASCO, J. K. Pesquisa de bioativos com atividade antimicrobiana nos extratos hidroetanólicos do fruto, folha e casca de caule do Zizyphus joazeiro Mart. Revista da Universidade Vale do Rio Verde, Três Corações, v. 10, n. 2, p. 43-51, 2012.

PAES, J. B.; MEDEIROS NETO, P. N.; LIMA, C. R.; FREITAS, M. F.; DINIZ, C. E. F. Efeitos dos extrativos e cinzas na resistência natural de quatro madeiras a cupins xilófagos. Cerne, Lavras-MG, v. 19, n. 3, p. 399-405, 2013.

PAVAN, A. R.; SILVA, G. D. B.; JORNADA, D. H.; CHIBA, D. E.; FERNANDES, G. F. S; CHIN, C. M.; SANTOS, J. L. Unraveling the anticancer effect of curcumin and resveratrol. Nutrients, Basel, v. 8, p. 628-, 2016.

PERIOTTO, G. Tabela de valores de absorção no espectro de infravermelho para compostos orgânicos. São Carlos: UFSCar, 2012, 6p.

PONGRAC, P.; ZHAO, F. J.; RAZINGER, J.; ZRIMEC, A.; REGVAR, M. Physiological responces to Cd and Zn in two $\mathrm{Cd} / \mathrm{Zn}$ hyperaccumulating Thlaspi species. Environtal and Experimental Botany, [n.1.], v. 66, p. 479486, 2009.

RIBEIRO, C. M. R.; SOUZA, N. A. Esquema geral para elucidação de substâncias orgânicas usando métodos espectroscópico e espectrométrico. Química Nova, São Paulo, v. 30, n. 4, 2007.

ROZWALKA, L. C.; LIMA, M. L. R. Z. C.; MIO, L. L. M.; NAKASHIMA, T. Extratos, decoctos e óleos essenciais de plantas medicinais e aromáticas na inibição de Glomerella cingulata e Colletotrichum gloeosporioides de frutos de goiaba. Ciência Rural, Santa Maria, v. 38, n. 2, p. 301-307, 2008.

SANTOS, G. A.; SANTOS, A. P.; KORNDÖRFER, G. H. Sistema por infravermelho próximo (NIR) para análises de nitrogênio foliar. Bioscience Journal, Uberlândia, v. 28, n. 1, p. 83-90, 2012.

SILVA, T. C.; ARAUJO, E. C. G.; LINS, T. R. S.; REIS, C. A.; SANQUETTA, C. R.; ROCHA, M. P. Non-timber forest products in Brazil: a bibliometric and a state of the art review. Sustainability, Basel, v. 12, n. 17, p. 1-24, 2020. 
SJÖSTRÖM, E. Wood chemistry: fundamentals and application. 2 ed. Londres: Academic Press, 1993, 293p. VAZ JÚNIOR, S. Análise química da biomassa. Brasília: Embrapa, 2015, 146p.

VILAR, M. S. A.; SOUZA, G. L.; VILAR, D. A.; LEITE, J. A.; RAFFIN, F. N.; BARBOSA-FILHO, J. M.; NOGUEIRA, F. H. A.; RODRIGUES-MASCARENHAS, S.; MOURA, T. F. A. L. Assessment of phenolic compounds and anti-inflammatory activity of ethyl acetate phase of Anacardium occidentale L. bark. Molecules, Basel, v. 21, 1087-, 2016.

WANG, W.-H.; CHIANG, I.-T; DING, K.; CHUNG, J.-G.; LIN, W.-J.; LIN, S.-S.; HWANG, J.-J. Curcumininduced apoptosis in human hepatocellular carcinoma j5 cells: critical role of $\left(\mathrm{Ca}^{+2}\right)$-dependent pathway. Evidence-Based Complementary and Alternative Medicine, London, v. 2012, p. 1-7, 2012. 